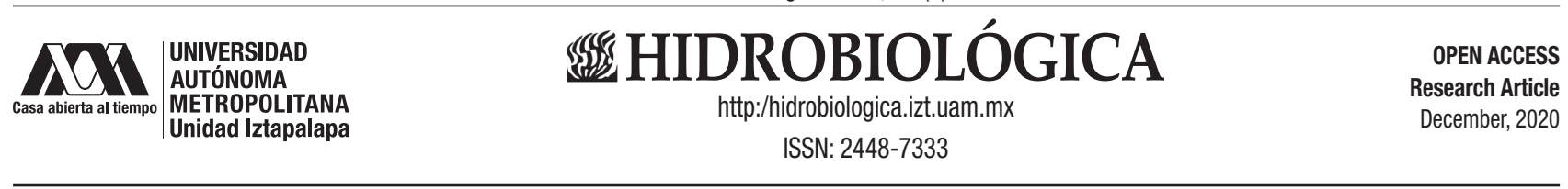

\title{
Hydromedusae (Cnidaria: Hydrozoa) from the coastal lagoon of Bocas de Dzilam, Yucatán
}

\author{
Hidromedusas (Cnidaria: Hidrozoa) de la laguna costera de Bocas de Dzilam, Yucatán
}

José María Ahuatzin-Hernández ${ }^{1 \oplus}$, Jesús Andrés Canul-Cabrera² ${ }^{2}$ Candita Mariana Eúan-Canul² and Lorena Violeta León-Deniz ${ }^{2 *}$

Departamento de Recursos del Mar, CINVESTAV-IPN, Unidad Mérida. Antigua carretera a Progreso, Km 6, Mérida, Yucatán 97310. México.

2 Facultad de Medicina Veterinaria y Zootecnia, Universidad Autónoma de Yucatán. Carretera Mérida-Xmatkuil, Km 15.5, Yucatán, 97100. México

*Corresponding author:

Lorena Violeta León-Deniz: e-mail: lorena. leon@correo.uady.mx.

To quote as:

Ahuatzin-Hernández, J. M., J. A. Canul Cabrera, C. M. Eúan-Canul \& L. V. LeónDeniz. 2020. Hydromedusae (Cnidaria Hydrozoa)from the coastal lagoon of Bocas de Dzilam, Yucatán. Hidrobiológica 30 (3) 221-231.

DOl:10.24275/uam/izt/dcbs/hidro/2020v30n3/ Ahuatzin

\section{ABSTRACT}

Background: Hydrozoan populations have an important role on the dynamic of the coastal ecosystems. However, the studies on hydromedusae in coastal lagoons from the Yucatán State are scarce. Goals: This study focuses on describe the first taxonomic list of hydromedusae in a coastal lagoon of the State of Yucatan. Methods: Samples were obtained through circular surface trawls using a zooplankton net in the coastal lagoon of Bocas de Dzilam. Six sampling stations were established inside the lagoon and eight outside, in adjacent zones to the mouth of the lagoon. The collected hydromedusae were fixed in a $4 \%$ formalin solution and identified with specialized literature. Results: Nine hydromedusae were identified, grouped into three orders and eight families, from which Hydractinia carica constitutes a new record for the Gulf of Mexico; the descriptions and images of the specimens are presented in the paper. Conclusions: These results set a basis to start understanding the composition of hydromedusae in the coastal lagoon of Dzilam and continue researching about this complex group in the coasts of Yucatán. However, further research efforts are required in coastal environments of the peninsula, in order to better understand its species composition and richness.

Keywords: First record, Gulf of Mexico, medusae, richness.

\section{RESUMEN}

Antecedentes: Las poblaciones de hidrozoos tienen un papel importante en la dinámica de los ecosistemas costeros. Sin embargo, los estudios sobre hidromedusas en lagunas costeras del estado de Yucatán son escasos. Objetivos: Este trabajo se centra en describir los ejemplares del primer listado taxonómico de hidromedusas en una laguna costera del estado de Yucatán. Métodos: Los ejemplares fueron obtenidos a través de arrastres zooplanctónicos circulares y de manera superficial en la laguna de Bocas de Dzilam. Seis estaciones de muestreo se establecieron en la parte interna de la laguna y ocho en la parte externa, en zonas adyacentes a la boca. Las medusas fueron fijadas en una solución formalina al $4 \%$ e identificadas con ayuda de literatura especializada. Resultados: Se identificaron nueve hidromedusas, dividas en tres órdenes y ocho familias, de las cuales Hydractinia carica constituye un nuevo registro para el Golfo de México; en el documento se proveen las descripciones e imágenes de los organismos analizados. Conclusiones: El presente trabajo establece una base para entender la composición de hidromedusas en la laguna costera de Dzilam y continuar investigando sobre este complejo grupo en las costas de Yucatán. Sin embargo, se requieren mayores esfuerzos de investigación con respecto a ecosistemas costeros de la península, a fin de comprender mejor su composición y riqueza de especies.

Palabras clave: Golfo de México, medusae, primer registro, riqueza. 


\section{INTRODUCTION}

Hydromedusae have an important role in coastal ecosystems due to their biological and ecological features. They can feed on several planktonic organisms, such as copepods, other hydromedusae or even commercially important fish or invertebrate larvae (Cortés-Lacomba et al., 2013). On the other hand, its distribution in the water column is limited and depends on the patterns of marine currents. Thus, they can be used as indicators of water masses and their movements (Martell-Hernández et al., 2014). Like other members of gelatinous zooplankton, their massive proliferation, together with its predatory features makes of them top predators, which can generate an imbalance in food chains (Boero et al., 2008). However, when their densities are controlled, these can act as regulators of other populations, being an important component of the diversity of an ecosystem and creating a link between pelagic and benthonic environments (Ronowicz et al., 2019).

Coastal lagoons of Yucatán provide many ecosystem services, such as recreation, fishing and coastal protection, among others (Kaplowitz, 2000). Unfortunately, several areas are highly perturbed by the urban growth, which causes low water quality and high levels of eutrophication, factors sometimes associated with high abundance of some medusae species (Herrera-Silveira \& Morales-0jeda, 2010). The coastal lagoon of Bocas de Dzilam is part of the Dzilam State Reserve and it was created to protect its species richness. The fauna inventory for this reserve is focused mainly on vertebrate's species (481), such as birds (221) and fishes (152), having only 23 species of marine invertebrates reported in the literature of the area (Diario Oficial de la Federación, 2018; AhuatzinHernández et al., 2019; Herrera-Bojórquez et al., in press).

Knowledge of species composition from an ecosystem is one of the most basic aspects on biodiversity research (Nascimento et al., 2018). To provide this information enriches the value of an ecosystem and allow to implement better natural resource managements (Gravili et al., 2013). In this sense, this paper provides the first taxonomic list of hydromedusae from Bocas de Dzilam lagoon, increasing the number of marine invertebrate species in the Management Plan of the Reserve and makes the first record of Hydractinia carica Bergh, 1887 for the Gulf of Mexico.

\section{MATERIALS AND METHODS}

Study area. Bocas de Dzilam lagoon is located on the northern of Yu-

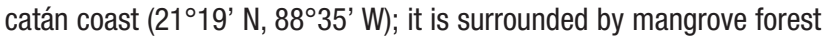
(mainly Rhizophora racemosa Meyer and Laguncularia racemosa (L.) C.F. Gaertn) and it is connected to the sea by a channel located in its central region.The salinity levels are generally estuarine (26.5\%o $2 \pm$ $38.9)$, however it can reach euhaline and hyperhaline conditions in dry season (March-June) (Herrera-Silveira \& Morales-0jeda, 2010; ReyesMendoza et al., 2020). This is a shallow lagoon (0.6 meters on average) with the influence of freshwater outcrops (Herrera-Silveira \& RamírezRamírez, 1998). Its bottom is covered mainly by the sea grasses: Halodule wrightii Ascherson, 1868, Thalassia testudinum K. D. Koenig, 1805, Syringodium filiforme Kützing, 1860 and Ruppia maritima Linnaeus, 1753. However, it can be also covered either by sand, shells or hard stones (Rosado-Espinosa et al., 2012). Some investigations on zooplankton has been made in the area, where the Copepods has been the main group in abundance. Also has been reported the presence of the Cubozoan Tripedalia cystophora Conant, 1897; however, hydromedusae are not mentioned in these studies (Herrera-Silveira \& Morales-0jeda, 2010; Marina et al., 2017; Ahuatzin-Hernández et al., 2019).

Samples were obtained during the night of 07 and 05 March 2017 and 2018, respectively. The circular trawls were carried out using a zooplankton net of $60 \mathrm{~cm}$ of diameter and $333 \mu \mathrm{m}$ of clear mesh. The samples were obtained as part of the field work in the subject of Marine Invertebrates of the Universidad Autónoma de Yucatán (UADY), so it was not possible to measure neither the volume of filtered water nor environmental parameters for each trawl. Six sampling stations were located inside the lagoon and eight outside, in adjacent zones to the mouth (Fig. 1). The zooplankton samples were fixed in a $4 \%$ formalin solution. All the samples were analyzed, and the hydromedusae were separated and counted. The specimens were identified according to Russell (1953), Kramp (1959) and Bouillon et al. (2006) and the bestpreserved were deposited in the zoological collection of invertebrates (YUC-CC) from the Universidad Autónoma de Yucatán (UADY). The relative abundance was calculated based on the total abundance of the specimens found in the study. The sampling stations where each species was found are indicated in the section of material examined.

\section{RESULTS}

A total of 437 specimens were collected. Nine taxa were recognized, two were identified up to the genus level and seven up to species level. The hydromedusae were grouped into three orders and eight families. The taxonomic arrangement follows Schuchert (2020) (Table 1). The data of the collected material is provided below.

\section{Order Anthoatecata \\ Family Bougainvilliidae Lûtken, 1850 \\ Bougainvillia muscus (Allman, 1863) (Fig. 2)}

Material examined. Mexico; Yucatan, Dzilam de Bravo; five specimens collected; sampling stations: 2, 4 (I); 6 (0); March 2017, 2018.

Description. Umbrella $3.5 \mathrm{~mm}$ high and wide, dome-like, jelly thick; velum well developed; manubrium short and broad with a cruciform base; four interradial gonads attached to manubrium; simple mouth with four long oral tentacles dichotomically branched; four marginal bulbs, slightly oval longitudinally, each with three reddish-brown adaxial ocelli and filiform tentacles, same in number with the ocelli.

Remarks. The taxonomic history of $B$. muscus has been complex due to its medusae stage presents numerous morphological variations, which has caused that other species were synonymized with the former. The main morphological variations in the species are in the number of marginal tentacles and branching of the oral tentacles (Vannucci-Mendez \& Rees, 1961; Schuchert, 2007). For this reason, the identification of some Bougainvillia species are hard to establish (Nagata et al., 2014). Despite its morphological plasticity, B. muscus has one of the simplest morphologies of the genus, so the shape and size of the manubrium, the position of the gonads, ramification of the oral tentacles (1-2 times), number of marginal tentacles per bulb (3-4), as well as the number of ocelli (3-4), can be used as a taxonomic configuration to define mature specimens (Kramp, 1959; Vannucci-Mendez \& Rees, 1961; Bouillon et al., 2004). In this sense, the specimens analyzed in this study match with the features mentioned above. However, molecular analyzes are required to establish better taxonomic boundaries between Bougainvillia species, in order to clarify its taxonomic status (Denitto et al., 2007). 


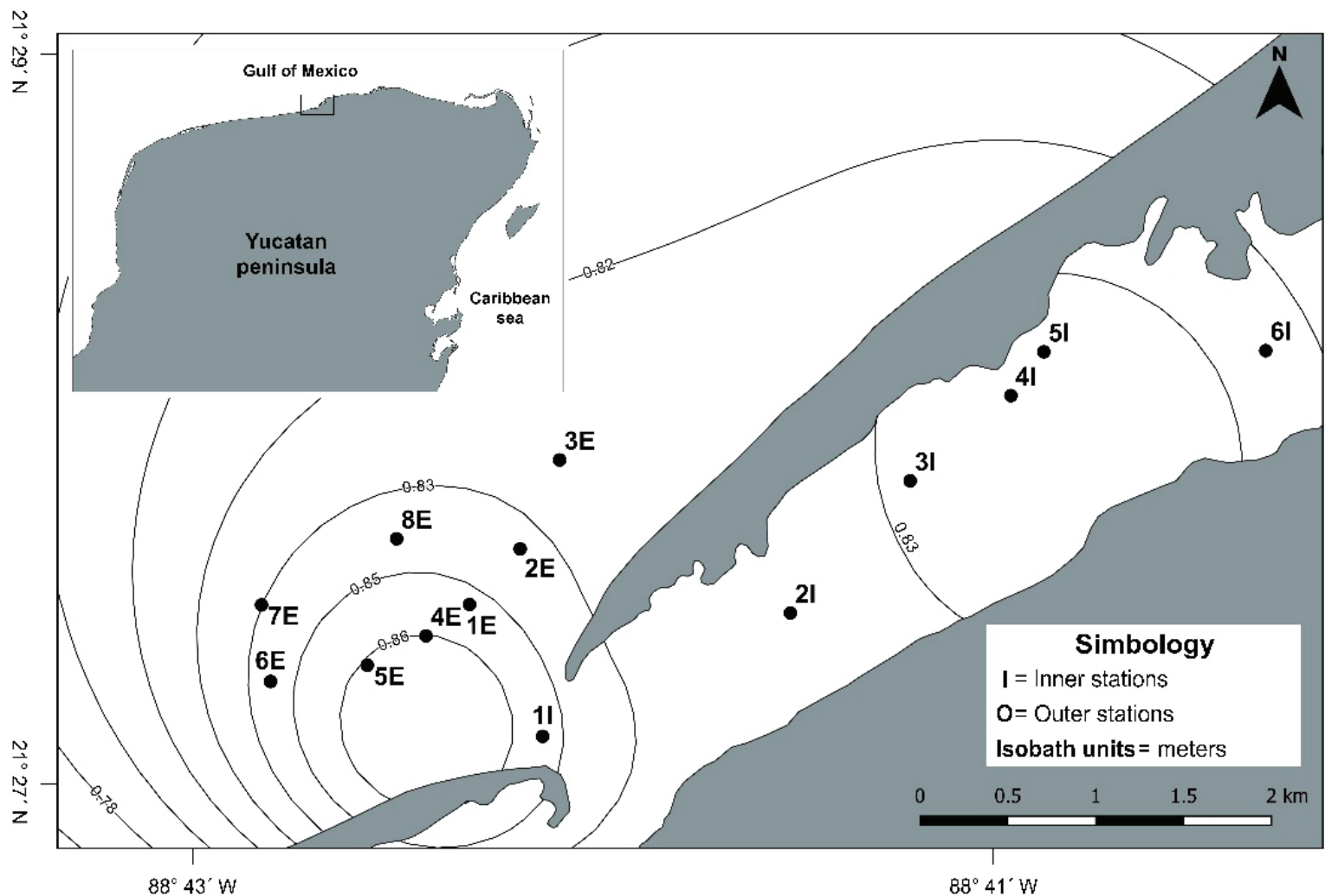

Figure 1. Map of Dzilam lagoon with the sampling stations. Isobaths calculated from Herrera-Silveira (1997).

Bougainvillia muscus has a widespread distribution, it has been recorded in the Pacific, Atlantic and Indian oceans, going from North Atlantic Ocean, including Mediterranean Sea, South Atlantic, Arctic Ocean, and Indo-Pacific to West Africa (Cortés-Lacomba et al., 2013; MendozaBecerril \& Marques, 2013).

Previous records in the Gulf of Mexico: Laguna Madre (MendozaBecerril, 2006); 18²8'52" - 2050'39" N and 91'15'43"- 9449'59" W (Loman-Ramos et al., 2007), Laguna de Términos (Cortés-Lacomba et al., 2013); $18^{\circ} \mathrm{N}, 95^{\circ} \mathrm{W}$ and $21^{\circ} \mathrm{N}, 91^{\circ} \mathrm{W}$ (Martell-Hernández et al., 2014); Pelican Island, Galveston (Pruski \& Miglietta, 2019).

\section{Family Corynidae Johnston, 1836}

\section{Sarsia tubulosa (M. Sars, 1835) (Fig. 3)}

Material examined. Mexico; Yucatan, Dzilam de Bravo; 34 specimens collected; sampling stations: 2 (I); 6, 7 (0); March 2017, 2018.

Description. Umbrella $2 \mathrm{~mm}$ high and $1.5 \mathrm{~mm}$ wide, bell-shaped, with the presence of a short narrow apical canal; manubrium long, extending beyond of the umbrellar cavity, with a gonadal ring in the distal part, near to the tubular mouth; four rounded bulbs, each with an abaxial ocellus; four moniliform tentacles with the middle-terminal part covered of nematocysts and with a terminal knob.

Remarks. Sarsia tubulosa is the type species of the genus. It can be distinguished from most of its congeners by its long tubular manubrium, which can be up to three times the length of the umbrella and it is surrounded by a gonadal ring (Bouillon et al., 2004). Sarsia tubulosa and S. Iovenii (M. Sars, 1846) are very similar morphologically, however, the latter has not been recorded for the Gulf of Mexico yet. The features that allow to distinguish $S$. tubulosa from $S$. Iovenii are: a smaller umbrella in adult specimens; rounded bulbs with greenish and orange colorations and gonads located in the distal part of the manubrium, covering 2/3 of it (Kramp, 1959; Jung, 2003; Prudkovsky et al., 2019). Most of the specimens in this study presented the umbrella everted inside out, however, the features previously mentioned were distinguished.

This is a mainly boreal species; however, it has been also recorded in tropical zones (Mendoza-Becerril et al., 2009). Its distribution goes from Norway, British Isles, North Sea, Danish waters and Greenland to the Pacific coasts of America, North Atlantic and Gulf of Mexico (Jung, 2003).

Previous records in the Gulf of Mexico: Laguna Madre (MendozaBecerril et al., 2009).

\section{Family Corymorphidae Allman, 1872}

\section{Corymorpha nutans M. Sars, 1835 (Fig. 4)}

Material examined. Mexico; Yucatan, Dzilam de Bravo; five specimens collected; sampling stations: 2, 4, 7 (0); March2018.

Description. Umbrella $1.2 \mathrm{~mm}$ high and wide, bell-shaped, with a conical apical projection of $1 / 4$ length of umbrella size and a narrow apical canal about as long as the apical projection; manubrium about as long as the umbrellar cavity, with a simple mouth; gonads surrounding the manubrium; four marginal bulbs, three rudimentary and one with a well-developed tentacle with a terminal knob. 
Remarks. The two most common species from the genus Corymorpha in the Gulf of Mexico are C. nutans and C. gracilis (Brooks, 1883) (Martell-Hernández et al., 2014; Pruski \& Miglietta, 2019). The main differences among these species are the length of the apical projection and the marginal bulbs. In $C$. gracilis, the apical projection is about as the length of the umbrella and has four tentacular bulbs, two of them rudimentary (without tentacles); of the remaining two bulbs, one bears a well-developed tentacle, opposite to a short and conical tentacle. On the other hand, in $C$. nutans, the apical projection is not that long and only having a well-developed tentacle and three rudimentary bulbs (Kramp, 1959; Nagata et al., 2014).

Corymorpha nutans is a mostly boreal species, its distribution goes from the Atlantic coasts of Northwestern Europe, Northern France and Norwegian coast, including Mediterranean Sea and Black Sea (Vervoort, 2009) to the tropical seas in the Gulf of Mexico (Loman-Ramos et al., 2007).

Previous records in the Gulf of Mexico: $18^{\circ} 28^{\prime} 52^{\prime \prime}-20^{\circ} 50^{\prime} 39$ " N and 91¹5'43"- 9449'59" W (Loman-Ramos et al., 2007); Pelican Island, Galveston (Pruski \& Miglietta, 2019).

\section{Family Oceaniidae Eschscholtz, 1829 \\ Turritopsis nutricula McCrady, 1857 (Fig. 5)}

Material examined. Mexico; Yucatan, Dzilam de Bravo; one specimen collected; sampling station: 8 (0); March 2018.

Description. Umbrella $1 \mathrm{~mm}$ high and 0.8 wide, bell-shaped, with four broad radial canals; manubrium short, brown, with vacuolated endodermal cells above stomach; four lips well defined in the mouth; numerous marginal bulbs, each with the presence of reddish-brown ocellus.

Remarks. The systematics of Turritopsis has been focus of debate, since its cryptic speciation has occasioned that several species around the world were synonymized with the cosmopolitan T. nutricula (Kubota, 2005). However, nowadays geographical populations are differentiated more clearly, and molecular studies suggest that $T$. nutricula is the only species of the genus from the Eastern coast of America (Miglietta et al., 2007). Despite this, more investigations are still needed on the taxonomy of this group.

This species is mainly distributed in Western Atlantic, from New England, the coast of Argentina, Mexico, and Brazil to some localities in the Pacific Ocean as Japan (Kubota, 2005; Nagata et al., 2014).

Table 1. Taxonomy of the Hydromedusae of the Dzilam lagoon and their abundance.

\begin{tabular}{|c|c|c|}
\hline Taxa & $\begin{array}{c}\text { Absolute } \\
\text { abundance (n) }\end{array}$ & $\begin{array}{c}\text { Relative } \\
\text { abundance (\%) }\end{array}$ \\
\hline \multicolumn{3}{|l|}{ Phylum Cnidaria } \\
\hline \multicolumn{3}{|l|}{ Class Hydrozoa Owen, 1843} \\
\hline \multicolumn{3}{|l|}{ Subclass Hydroidolina Collins, 2000} \\
\hline \multicolumn{3}{|l|}{ Order Leptothecata Cornelius, 1992} \\
\hline \multicolumn{3}{|l|}{ Family Campanulariidae Johnston, 1836} \\
\hline Obelia spp. Péron \& Lesueur, 1810 I, 0 & 134 & 0.307 \\
\hline Clytia spp. Lamouroux, 1812 I, 0 & 12 & 0.027 \\
\hline \multicolumn{3}{|l|}{ Order Anthoathecata Cornelius, 1992} \\
\hline \multicolumn{3}{|l|}{ Suborder Filifera Kühn, 1913} \\
\hline \multicolumn{3}{|l|}{ Family Bougainvilliidae Lütken, 1850} \\
\hline Bougainvillia muscus (Allman, 1863) I, 0 & 5 & 0.011 \\
\hline \multicolumn{3}{|l|}{ Family Oceanidae Eschscholtz, 1829} \\
\hline Turritopsis nutricula McCrady, 18570 & 1 & 0.002 \\
\hline \multicolumn{3}{|l|}{ Family Hydractiniidae L. Agassiz, 1862} \\
\hline Hydractinia carica Bergh, $18870^{*}$ & 47 & 0.108 \\
\hline \multicolumn{3}{|l|}{ Suborder Capitata Kühn, 1913} \\
\hline \multicolumn{3}{|l|}{ Family Corynidae Johnston, 1836} \\
\hline Sarsia tubulosa (M. Sars, 1835) I, 0 & 34 & 0.078 \\
\hline \multicolumn{3}{|l|}{ Family Cladonematidae Dujardin, 1843} \\
\hline Cladonema radiatum Dujardin, 1843 I & 5 & 0.011 \\
\hline \multicolumn{3}{|c|}{ Suborder Aplanulata Collins, Winkelman, Hadrys \& Schierwater, 2005} \\
\hline \multicolumn{3}{|c|}{ Family Corymorphidae Allman, 1872} \\
\hline Corymorpha nutans M. Sars, 18350 & 5 & 0.011 \\
\hline \multicolumn{3}{|l|}{ SubclassTrachylinae Haeckel, 1879} \\
\hline \multicolumn{3}{|l|}{ Order Limnomedusae Kramp, 1938} \\
\hline \multicolumn{3}{|l|}{ Family Olindiidae Haeckel, 1879} \\
\hline Vallentinia gabriellae (Vannucci Mendes, 1948) I, 0 & 194 & 0.444 \\
\hline Total & 437 & \\
\hline
\end{tabular}

Note. Species market with * constitute a new record for the Gulf of Mexico. I= species found inside the lagoon, $0=$ species found outside the lagoon 
Previous records in the Gulf of Mexico: $19^{\circ} \mathrm{N}, 85^{\circ} \mathrm{W}$ and $23^{\circ} \mathrm{N}, 90^{\circ} \mathrm{W}$ (Segura-Puertas, 1992 ); $18^{\circ} \mathrm{N}, 95^{\circ} \mathrm{W}$ and $21^{\circ} \mathrm{N} 91^{\circ} \mathrm{W}$ (Martell-Hernández et al., 2014).

\section{Family Hydractiniidae L. Agassiz, 1862}

\section{Hydractinia carica Bergh, 1887 (Fig. 6)}

Material examined. Mexico; Yucatan, Dzilam de Bravo; 47 specimens collected; sampling station: 8 (0); March 2017.

Description. Umbrella $0.5 \mathrm{~mm}$ high and wide, bell-shaped; manubrium short with a simple mouth, four short oral tentacles, each with a nematocysts cluster on the terminal part; gonads on the manubrium, with interradial medusa buds; eight marginal bulbs, without marginal tentacles; no ocelli.

Remarks. Hydractinia carica was synonymized as $H$. minuta Bonnevie, 1898. This species has been subject of several taxonomic debates (Wang et al., 2016). According with Schuchert (2007), H. carica should be removed from Hydractiniidae, since this species is regarded as a conspecific with Lizzia blondina Forbes, 1848. This species is easily recognizable from others within Hydractinia by the presence of oral tentacles well-developed and undivided, eight marginal bulbs, the absence of ocelli and the presence of medusa buds on the manubrium (Kramp, 1959), features that were observed in the specimens analyzed in this study.

Hydractinia carica has been previously reported from the West Africa, Adriatic Sea and Mediterranean to the Mexican Caribbean Sea (Kramp, 1959; Segura-Puertas et al., 2003; Schuchert, 2007).

Previous records in the Gulf of Mexico: No previous records for the Gulf of Mexico.

\section{Family Cladonematidae Gegenbaur, 1857}

\section{Cladonema radiatum Dujardin, 1843 (Fig. 7)}

Material examined. Mexico; Yucatán, Dzilam de Bravo; five specimens collected; sampling stations: 2, 4 (I); March 2018.

Description. Umbrella $1 \mathrm{~mm}$ high and 0.8 wide, bell-shaped, with an apical projection; manubrium about as long as bell cavity; with gonads on its upper middle part; tubular mouth, with six short oral tentacles, each with a cluster of nematocysts in the terminal part; nine radial canals, three bifurcated and three simple; nine elongated tentacular bulbs, each with a black abaxial ocellus and bearing two types of tentacles, first type is a multi-branched stinging tentacle with numerous nematocyst rings and second type are numerous single suctorial tentacles with a terminal nematocyst knob.

Remarks. The frequent morphological variations between the species of Cladonema difficult to establish a definitive taxonomy in the group. $C$. raditum is the best documented species of the genus and probably of the family Cladonematidae. Many morphologies have been documented in this species, which makes its taxonomic position uncertain (Russell, 1953). In this sense, C. radiatum has been frequently synonymized as C. perkinsii Mayer, 1904 and C. mayeri Perkins, 1906 (Hirai, 1958). The features that distinguish this species from its congeners are: gonads covering the upper middle part of the manubrium; nine radial canals, some of them bifurcated; six oral tentacles and marginal bulbs with two types of tentacles; first type with multi-branched stinging tentacles; and the second type with numerous suctorial tentacles (Schuchert, 2006; Cedeño-Posso, 2014).
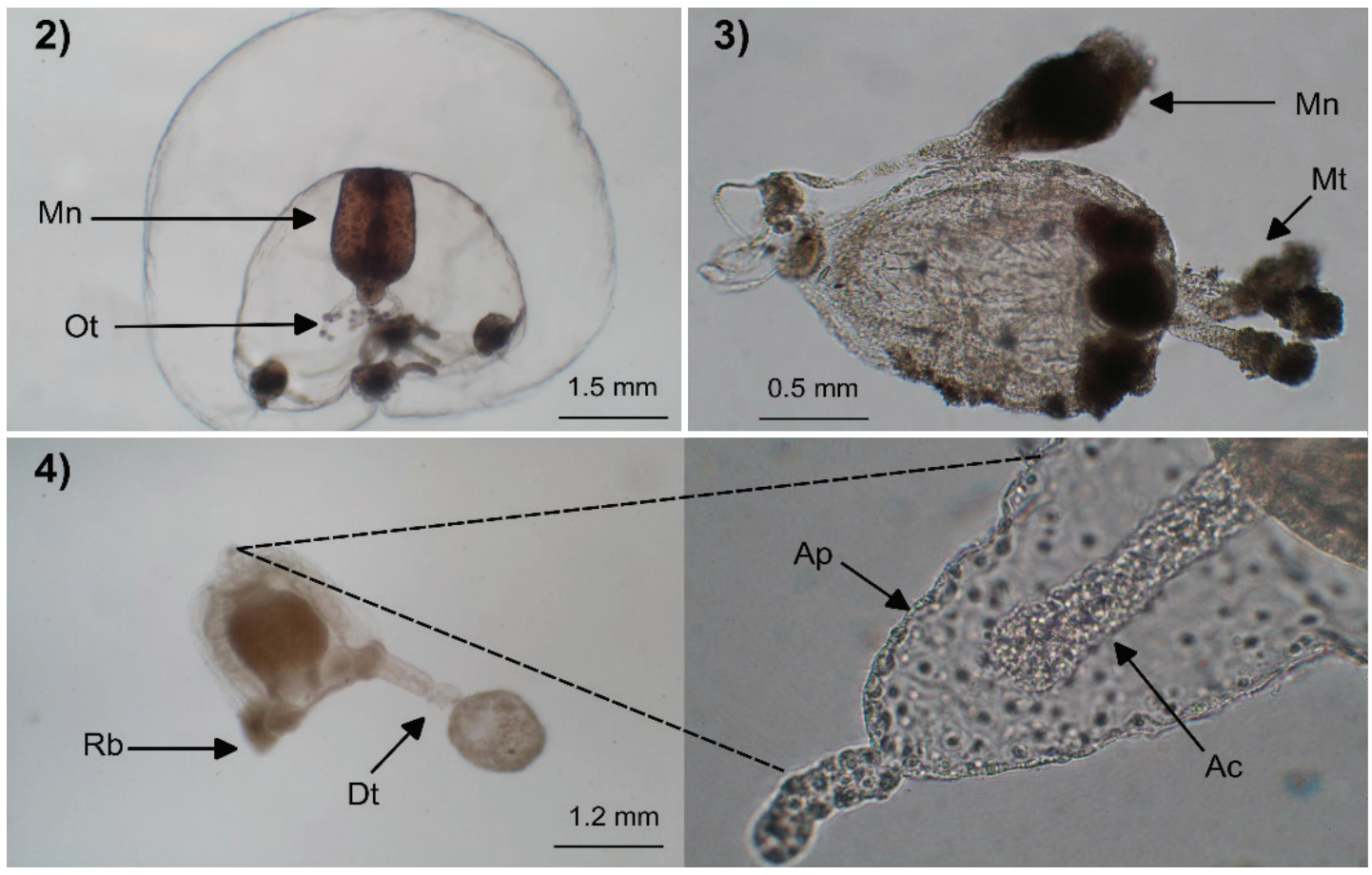

Figures 2-4. Bougainvillia muscus (2): $\mathrm{Mn}=$ manubrium, Ot=oral tentacles; Sarsia tubulosa (specimen everted inside out) (3): $\mathrm{Mn}=\mathrm{manubrium,} \mathrm{Mt}=\mathrm{marginal}$ tentacles; Corymorpha nutans (4): $\mathrm{Rb}=$ rudimentary bulb, $\mathrm{Dt}=$ well-developed tentacle, $\mathrm{Ap}=$ apical projection, $\mathrm{Ap}=$ apical canal. 

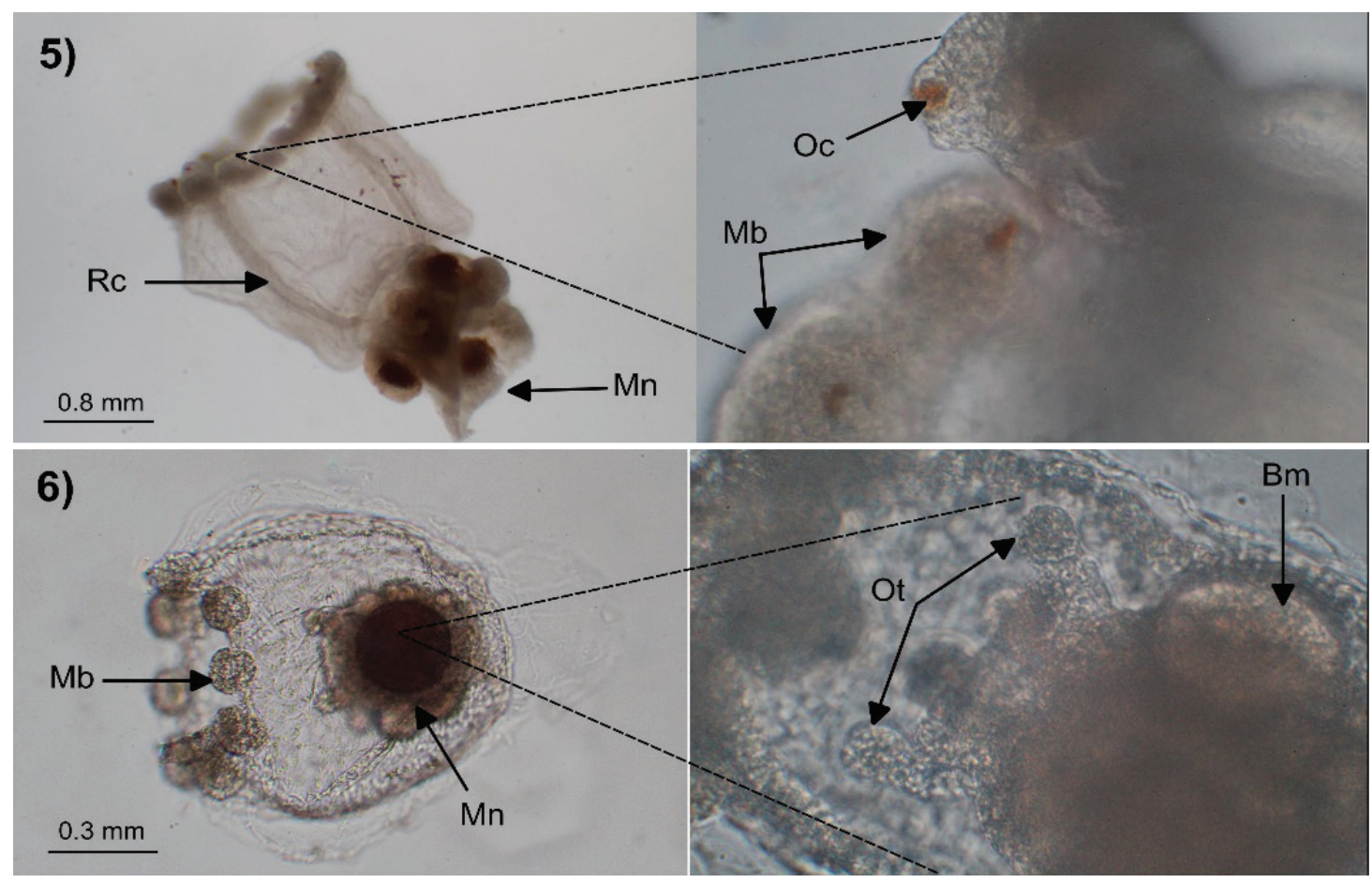

Figures 5-6. Turritopsis nutricula (specimen everted inside out) (5): $\mathrm{Rc}=$ radial canal, $\mathrm{Mn}=$ manubrium, $\mathrm{Oc}=0 \mathrm{cellus,} \mathrm{Mb}=$ marginal bulbs; Hydractinia carica (6): $\mathrm{Mn}=$ manubrium, $\mathrm{Mb}=$ marginal bulb, $0 \mathrm{t}=$ oral tentacles, $\mathrm{Bm}=$ medusa bud.

This species has been widely reported from the Atlantic Ocean, including Europe, the Mediterranean Sea and the Mexican Caribbean (Gershwin \& Zeidler, 2008; Cedeño-Posso, 2014).

Previous records in the Gulf of Mexico: Calder \& Cairns (2009) (as polyp stage).

\section{Order Leptothecata}

\section{Family Campanulariidae Johnston, 1836}

\section{Clytia spp. Lamouroux, 1812 (Fig. 8)}

Material examined. Mexico; Yucatan, Dzilam de Bravo; twelve specimens collected; sampling stations: 1, 5 (I); 3, 5, 7, 8 (0); March 2017, 2018.

Description. Umbrella $2 \mathrm{~mm}$ wide, hemispheric, jelly thin; manubrium small, short and with four well defined lips; four oval gonads, located on the middle part of the radial canals; up to twenty marginal bulbs, circulars and with short tentacles, each tentacular bulb alternating with rudimentary bulbs; umbrellar margin simple, only with small statocysts, each with one concretion and alternating with tentacular bulbs.

Remarks. Hydromedusae from genus Clytia are easily recognizable within the family Campanulariidae by the form of the umbrella, characteristic lips and umbrellar margin simple (Bouillon et al., 2006). Few species of Clytia are identifiable using only the morphological features of the medusa stage, due to the great morphological plasticity in some features like size, shape and position of the gonads and number of tentacles and statocysts (Nogueira-Jr, 2012; Nagata et al., 2014). The specimens analyzed in this study showed immature and bad preserve features, so, it was not possible to define a species. However, it was possible to identify them up to genus level by the features previously mentioned.

The genus Clytia is considered cosmopolitan and most of its species are related to coastal environments (Russell, 1953; Nagata et al., 2014).

Previous records in the Gulf of Mexico: Some of the main records of Clytia species in the region are: $18^{\circ} 28^{\prime} 52$ " - 20 $20^{\prime} 39^{\prime \prime} \mathrm{N}$ and 9115'43"- 9449'59" W (Loman-Ramos et al., 2007); Laguna Madre (Mendoza-Becerril et al., 2009); Laguna de Términos (Cortés-Lacomba et al., 2013); $18^{\circ} \mathrm{N}, 95^{\circ} \mathrm{W}$ and $21^{\circ} \mathrm{N} 91^{\circ} \mathrm{W}$ (Martell-Hernández et al., 2014); Pelican Island, Galveston (Pruski \& Miglietta, 2019).

\section{Obelia spp. Péron \& Lesueur, 1810 (Fig. 9)}

Material examined. Mexico; Yucatan, Dzilam de Bravo; 134 specimens collected; sampling stations: 1, 2, 3, 4, 5 (I); 2, 3, 6, 7, 8 (0); March 2017, 2018.

Description. Umbrella $1.5 \mathrm{~mm}$ wide, flat, with a rudimentary velum; jelly thin; four circular gonads located on the middle part of the radial canals; manubrium short, with a quadrangular base and four simple lips; many short tentacles, solids and around all the umbrellar margin; numerous statocysts, each with one concretion.

Remarks. Obelia is unmistakable within the family Campanulariidae due to it is the only genus of hydromedusae with rudimentary velum and with an umbrella completely flat (Bouillon et al., 2006). However, the medusa of Obelia do not have morphological features for a specific identification, therefore, sometimes the hydroid stage is required for an accurate determination. The genus is among the most variable morphologically and some species as 0 . dichotoma (Linnaeus, 1758) are considered crypto- 
genic because of its multiple records around the world (Humara-Gil \& Cruz-Gómez, 2018).This is a genus with a worldwide distribution and frequently related to coastal zones (Nagata et al., 2014).

Previous records in the Gulf of Mexico: $19^{\circ} \mathrm{N}, 85^{\circ} \mathrm{W}$ and $23^{\circ} \mathrm{N}, 90^{\circ} \mathrm{W}$ (Segura-Puertas, 1992$) ; 18^{\circ} \mathrm{N}, 91^{\circ} \mathrm{W}$ and $20^{\circ} \mathrm{N}, 94^{\circ} \mathrm{W}$ (Loman-Ramos et al., 2007); $18^{\circ} \mathrm{N}, 95^{\circ} \mathrm{W}$ and $21^{\circ} \mathrm{N} 91^{\circ} \mathrm{W}$ (Martell-Hernández et al., 2014); Tamaulipas coast (Gutiérrez-Aguirre et al., 2015); Pelican Island, Galveston (Pruski \& Miglietta, 2019).

\section{Order Limnomdusae}

\section{Family Olindiidae Haeckel, 1879}

\section{Vallentinia gabriellae Vannucci Mendes, 1948 (Fig. 10)}

Material examined. Mexico; Yucatan, Dzilam de Bravo; 194 specimens collected; sampling stations: 1, 2, 3, 4, 5 (I);2, 4, 6, 7, 8 (0); March 2017, 2018.

Description. Umbrella $7 \mathrm{~mm}$ wide, hemispheric, jelly thick; manubrium with four lips defined, gonads with papilliform process, located on the middle part of the four radial canals; two types of tentacles, first type arising from above the umbrellar margin and minor in number; second type arising from the margin of the umbrella; most of the tentacles with adhesive pads on its external side and with numerous nematocysts rings; a statocyst with one concretion between each tentacle.

Remarks. From the three valid species within Vallentinia, V. gabriellae can be distinguished from $V$. adherens Hyman, 1947 by the form of the umbrella, the form and location of the gonads and the lack of cirrus-like in the margin. Vallentinia falklandica Browne, 1902 is characterized by the presence of four perradial sucker tentacles, which were not observed in the material analyzed. The specimens analyzed match with the description of Kramp (1959) for V. gabriellae in the type and number of tentacles and form of the gonads and umbrella. The taxonomic keys of Kramp (1959) and Bouillon et al. (2004; 2006) point out the presence of adhesive pads in the terminal part of the tentacles as a distinctive feature to differentiate Vallentinia from Cubaia Mayer, 1894. However, the original description by Vannucci-Mendez (1948) mentions that the adhesive pads in mature specimens of $V$. gabriellae are on the external side of the tentacles, as observed in the specimens analyzed in this study. In this sense, it is desirable to clarify that the defining feature of Vallentinia is not exclusively the location of the adhesive pads as suggested by Kramp and Bouillon, but a set of morphological features such as those mentioned previously.

This species has been frequently reported related to mangrove ecosystems in the coast of Brazil and Caribbean Sea (Rey et al., 1992; Segura-Puertas \& Damas-Romero,1997; Ramos \& Segura-Puertas, 2004).

Previous records in the Gulf of Mexico: Progreso, Yucatán (Foster, 1973).

\section{DISCUSSION}

The number of species from Bocas de Dzilam is greater than the reported in other coastal lagoons in southern Gulf of Mexico (Cortés-Lacomba et al., 2013) and its composition represent the $5.3 \%$ of the Medusozoa fauna reported in this region (Gasca \& Loman-Ramos, 2014). Only $S$. tubulosa and $B$. muscus have been reported in other coastal lagoons from southern Gulf of Mexico (Mendoza-Becerril et al., 2009; CortésLacomba et al., 2013).

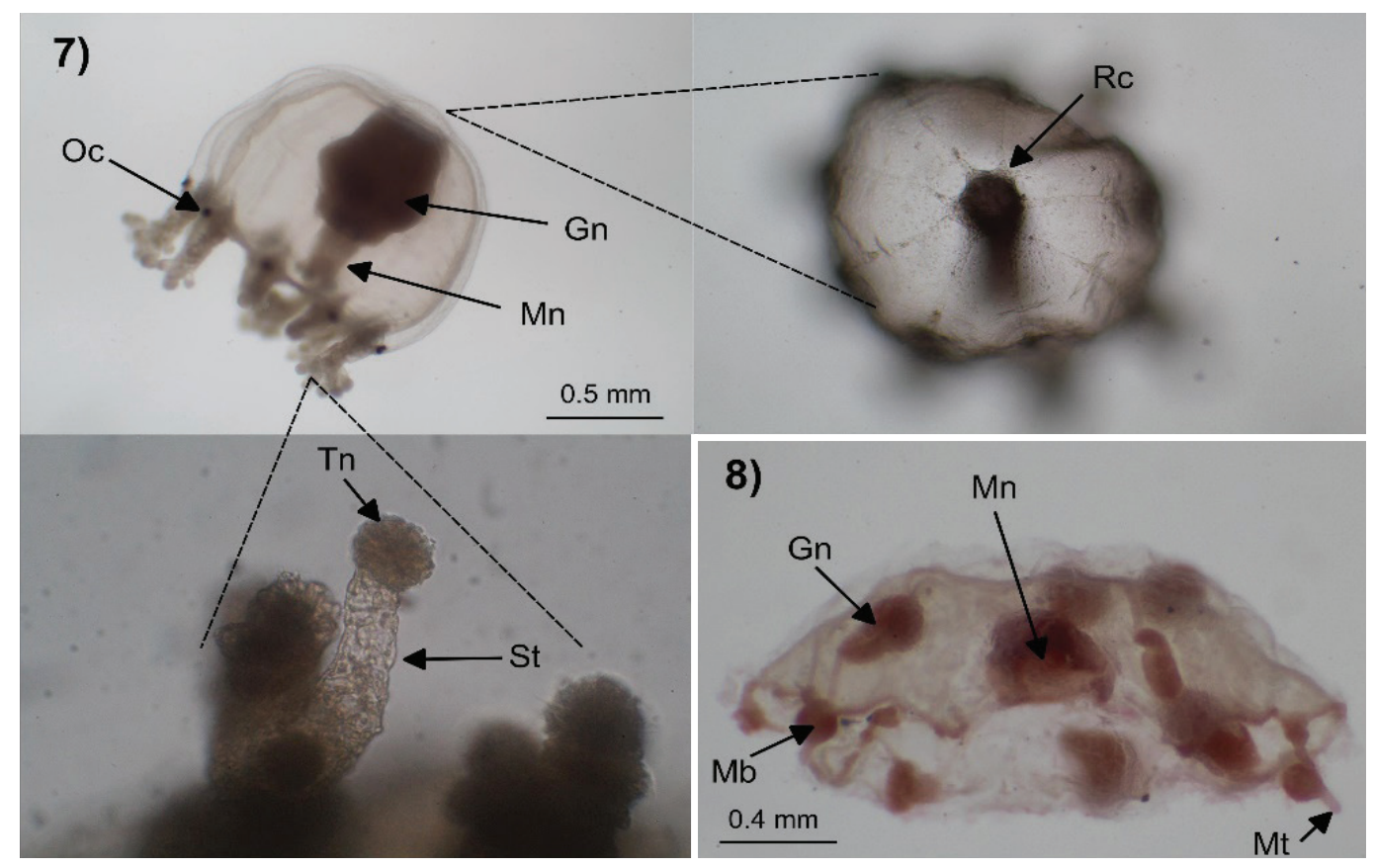

Figures 7-8. Cladonema radiatum (7): $\mathrm{Oc}=0$ cellus, $\mathrm{Mn}=$ manubrium, $\mathrm{Gn}=$ gonads, $\mathrm{Rc}=$ radial canals, $\mathrm{St}=$ sucker tentacle, $\mathrm{Tn}=$ terminal knob; $C / y t i a$ spp. (8): $\mathrm{Mn}=$ manubrium, $\mathrm{Gn}=$ gonads, $\mathrm{Mb}=$ marginal bulb, $\mathrm{Mt}=$ marginal tentacle. 


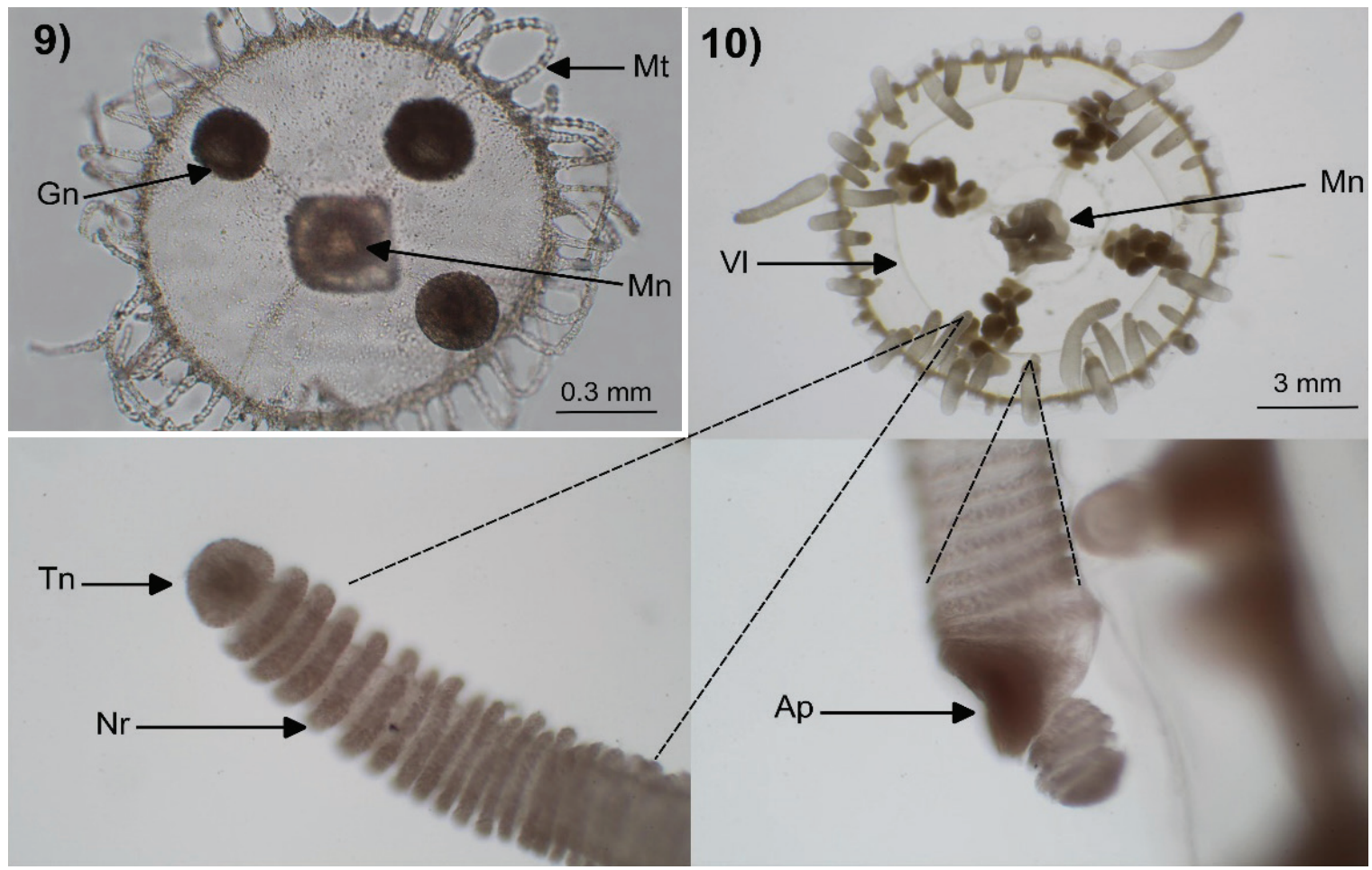

Figures 9-10. Obelia spp. (9): $\mathrm{Mn}=$ manubrium, Gn=gonads, Mt=marginal tentacle; Vallentinia gabriellae (10): $\mathrm{Mn}=$ manubrium, $\mathrm{Vl}=\mathrm{velum}, \mathrm{Ap}=\mathrm{adhesive}$ pad, $\mathrm{Tn}=$ terminal knob, $\mathrm{Nr}=$ nematocyst rings.

Vallentinia gabriellae, Obelia spp. and $H$. carica constituted more that $90 \%$ of the material collected. Vallentinia gabriellae has been reported not so abundant in the Mexican Caribbean $(0.3 \%$ of relative abundance) (Segura-Puertas \& Damas-Romero, 1997; Ramos \& Segura-Puertas, 2004) compared to this study. This suggest that the lagoon of Dzilam could provide favorable conditions for its development. The high contribution of Obelia coincides with the reported by Nogueira-Jr (2012) and Nagata et al. (2014), since this is one of the most abundant and common hydromedusae from coastal zones. Likewise, the relative abundance of $H$. carica was higher in this study compared with others from the Mexican Caribbean ( $0.1 \%$ of relative abundance) (Ramos \& Segura-Puertas, 2004). This species was found only in one outer sta- tion, which suggests a probable medusa budding on the sampling site. The southern Gulf of Mexico and Mexican Caribbean have a constant exchange of marine currents (i.e. Yucatan current), which play an important role in the development and distribution of numerous zooplanktonic organisms (Candela et al., 2002; Manzanilla-Dominguez \& Gasca, 2004) and greatly favors the similarity in its planktonic composition. In this sense, the presence of $H$. carica in the Gulf of Mexico is not surprising, since it has already been previously reported in the Mexican Caribbean. Considering the previously mentioned, the absence of some species either in Gulf of Mexico or Mexican Caribbean encourages more systematic investigations that allows to define better ecological distribution in zooplanktonic organisms between these two regions (Table 2).

Table 2. Previous records of the hydromedusae of Dzilam lagoon in the Gulf of Mexico and Mexican Caribbean. Presence (X). Absent (--).

\begin{tabular}{lccl}
\hline Taxa & $\begin{array}{c}\text { Gulf of } \\
\text { Mexico }\end{array}$ & $\begin{array}{c}\text { Mexican } \\
\text { Caribbean }\end{array}$ & References \\
\hline Obelia sp. & $\mathrm{X}$ & $\mathrm{X}$ & Segura-Puertas \& Damas-Romero (1997); Martell-Hernández et al. (2014). \\
Clytia sp. & $\mathrm{X}$ & $\mathrm{X}$ & Ramos \& Segura-Puertas (2004); Loman-Ramos et al. (2007). \\
B. muscus & $\mathrm{X}$ & $\mathrm{X}$ & Segura-Puertas et al. (2003); Cortés-Lacomba et al. (2013). \\
T. nutricula & $\mathrm{X}$ & -- & Segura-Puertas et al. (2003). \\
H. carica & -- & $\mathrm{X}$ & Ramos \& Segura-Puertas (2004). \\
S. tubulosa & $\mathrm{X}$ & -- & Mendoza-Becerril et al. (2009) \\
C. radiatum & $\mathrm{X}$ & $\mathrm{X}$ & Segura-Puertas et al. (2003);Calder \& Cairns (2009). \\
C. nutans & $\mathrm{X}$ & -- & Loman-Ramos et al. (2007). \\
V. gabriellae & $\mathrm{X}$ & $\mathrm{X}$ & Foster (1973); Ramos \& Segura-Puertas (2004). \\
\hline
\end{tabular}


The rest of the material collected was constituted by B. muscus, Clytia spp., T. nutricula, $S$. tubulosa, and $C$. nutans. The low contribution of $T$. nutricula and $C$. nutans has been also reported in other coastal investigations (Nagata et al., 2014; Pruski \& Miglietta, 2019). Bougainvillia muscus (18.03\%), S. tubulosa (2.5\%) and Clytia spp. (0.003\%), are usually abundant from coastal zones (Costello \& Mathieu, 1995; Mendoza-Becerril et al., 2009; Cortés-Lacomba et al., 2013; Nagata et al., 2014) which not match with this study, probably by the high levels of salinity and temperature associated with the seasonality of the study area.

On the other hand, Clytia spp., B. muscus, Obelia spp., S. tubulosa, and $V$. gabriellae were found either inside and outside the lagoon, which match with previous reports in coastal zones from the Gulf of Mexico (Loman-Ramos et al., 2007; Mendoza-Becerril et al., 2009; CortésLacomba et al., 2013). Vallentinia gabriellae does not appear in the listings of medusae from the Gulf of Mexico (Segura-Puertas et al., 2003, 2009), however, it is remarkable the evidence about its occurrence in shallow waters of Yucatán (Foster, 1973).

Turritopsis nutricula, C. nutans, and $H$. carica were found exclusively outside the lagoon. Turritopsis nutricula is common in the NorthWestern Atlantic (Miglietta et al., 2007) and it is related to offshore areas; however, it has been also found related to coastal ecosystems like in this study (Segura-Puertas, 1992; Nagata et al., 2014). Likewise, $C$. nutans is common in neritic and estuarine ecosystems from the Gulf of Mexico (Segura-Puertas et al., 2009), however, it is probable that also uses the lagoon as part of its life-cycle, since it has been also recorded in semi-closed ecosystems (Pruski \& Miglietta, 2019). On the other hand, $\mathrm{H}$. carica is not included in the last taxonomic listings of hydromedusae from the Gulf of Mexico (Segura-Puertas et al., 2003, 2009). This species only had been reported in the Caribbean Sea for Mexican coasts (Segura-Puertas et al., 2003). In this paper we report its occurrence for the first time in the Gulf of Mexico, expanding its distribution range toward northwest $\left(21^{\circ} \mathrm{N}-88^{\circ} \mathrm{W}\right)$.

Cladonema radiatum was the only species recorded exclusively within the lagoon. The medusa of Cladonema has adaptations (branched and sucker tentacles) for epibenthic habits (Cedeño-Posso, 2014) and the lagoon of Dzilam is a shallow ecosystem ( $0.6 \mathrm{~m}$ on average) with a high dominance of seagrasses and macroalgae in the bottom (HerreraSilveira \& Morales-0jeda, 2010). These features could favor its development inside the lagoon and explain its occurrence in this zone.

The management plan of Dzilam de Bravo State Reserve involves few researches on marine invertebrates (Diario Oficial de la Federación, 2018), and this lack makes the estimation of its biodiversity uncertain, which is fundamental for the elaboration of management and conservation plans. The studies on hydromedusae in coastal lagoons are important, since together with other members of the gelatinous zooplankton, they have an important role in the interchange of biomass between the trophic chains (Boero et al., 2008). In this sense, more investigations on hydrozoan composition in coastal ecosystems of Yucatán are needed, with the purpose of providing more information about its richness and better understand the biodiversity of the region.

\section{ACKNOWLEDGMENT}

The authors thanks to Pablo Hernández Solís for the samples processing and Dr. Gonzalo Mena Rejón for the comments and suggestions to the manuscript.

\section{REFERENCES}

Ahuatzin-Hernández, J. M., A. J. Cohuo-Concha, L. Loman-Ramos \& L. V. LeÓN-DenIz. 2019. Range expansion of two box jellyfish (Cnidaria, Cubozoa) in southern Gulf of Mexico. Checklist 15: 405-410. DOI:10.15560/15.3.405

Boero, F., J. Boulllon, C. Gravili, M. P. Miglietta, T. Parsons \& S. Piraino. 2008. Gelatinous plankton: irregularities rule the world (sometimes). Marine Ecology Progress Series 356: 299-310.

Boullion, J., M. D. Medel, F. Pagès, J. M. Gili, F. Boero \& C. Gravili. 2004 Fauna of the Mediterranean Hydrozoa. Scientia Marina 68 (supplement 2): 5-438.

Boullzon, J., C. Gravili, F. Pages, J. M. Gilı \& F. Boero. 2006. An introduction to Hydrozoa. Publications Scientifiques du Muséum, Paris. 591 p.

Calder, D. R. \& S. D. Cairns. 2009. Hydroids (Cnidaria: Hydrozoa) of the Gulf of Mexico. In: Felder, D. L \& D. K. Camp (eds.). Gulf of Mexico. Origin, Waters and Biota. Vol. 1 Biodiversity. Texas A \& M University Press. Texas, pp. 381-394.

Candela, J., J. Sheinbaum, J.0choa \& A. Badan. 2002. The potential vorticity flux through the Yucatan Channel and the Loop Current in the Gulf of Mexico. Geophysical Research Letters 29 (22): 2059.

Cedeño-Posso, C. 2014. First record of genus Cladonema (medusae and polyps) in Colombia. Zootaxa 3793: 597-599.

Cortés-Lacomba, R., C. Álvarez-Silva \& F. Gutiérrez-Mendieta. 2013. Listado actualizado de las medusas de la Laguna de Términos, Campeche, México. Hidrobiológica 23: 209-217.

Costello, J. H. \& H. W. Mathieu. 1995. Seasonal abundance of medusae in Eel Pond, Massachusetts, USA during 1990-1991. Journal of Plankton Research 17 (1): 199-204.

Denitto, F., M. P. Migletta \& F. Boero. 2007. Life cycle of Bougainvillia nana (Cnidaria: Hydrozoa: Bougainvilliidae) from Italy, including a discussion of Bougainvillia muscus in the Mediterranean Sea. Journal of the Marine Biological Association of the United Kingdom 87(4): 853-857.

DOF (Diario Oficial de la Federación). 2018. Actualización del Programa de Manejo Reserva Estatal de Dzilam, Yucatán, México. Gobierno del estado de Yucatán. Disponible en línea en: www.yucatan.gob.mx/ docs/diario_oficial/diarios/2018/2018-09-26_2.pdf (consultado el 11 julio 2019).

Foster, N. R. 1973. Occurrence of Vallentinia gabriellae (Hydrozoa: Olindiadidae) in Coastal Yucatan, with notes on its biology and laboratory culture. Proceedings of the Academy of Natural Sciences of Philadelphia 125: 69-74.

Gasca, R. \& L. Loman-Ramos. 2014. Biodiversidad de Medusozoa (Cubozoa, Scyphozoa e Hydrozoa) en México. Revista Mexicana de Biodiversidad 85: 154-163.

Gershwin, L. A. \& W. ZeiderR. 2008. Cladonema timmsii, a new species of hydromedusa (Cnidaria: Hydrozoa) from a salt lake in South Australia. Zootaxa 1826: 59-68.

Gravili, C., C. G. Di-Camilo, S. Piraino \& F. Boero. 2013. Hydrozoan species richness in the Mediterranean Sea: past and present. Marine Ecology 34 (Suppl. 1): 41-62. 
Gutiérrez-Aguirre, M. A., V. H. Delgado-Blas \& A. Cervantes-Martínez. 2015. Diversidad de las hidromedusas (Cnidaria) de la región nerítica del sureste de Tamaulipas, México. Teoría y Praxis 18: 153-167.

Herrera-Bojórquez, L. G., R. González-Muñoz, L. V. León-Deniz, G. ArjonaTorres \& R. Sima-Álvarez. In press. Sea anemones (Anthozoa: Actiniaria) from the coast of Yucatán, Mexico. Revista Mexicana de Biodiversidad.

Herrera-Silveira, J. A. 1997. Biodiversidad de productores primarios de lagunas costeras del norte de Yucatán, México. Instituto Politécnico Nacional. Centro de Investigación y de Estudios Avanzados-Mérida. Bases de datos SNIB2010-CONABI0, proyecto B019, 60 p.

Herrera-Silveira, J. A. \& J. Ramirez-Ramírez. 1998. Salinity and nutrients in the coastal lagoons of Yucatan, Mexico. Internationale Vereinigung für Theoretische und Angewandte Limnologie: Verhandlungen 26 (3): 1473-1478.

Herrera-Silveira, J. A. \& S. M. Morales-0Jeda. 2010. Subtropical Karstic Coastal Lagoon Assessment, SE Mexico. The Yucatan peninsula case. In: Kennish, M. J. \& H. W. Paerl (eds.). Coastal Lagoons: Critical Habitats of Environmental Change. CRC Press, Florida, pp. 309335.

HIRAI, E. 1958. On the species of Cladonema radiatum var. mayeri Perkins. Bulletin of the Marine Biological Station of Asamushi, Tohoku University 9: 23-25.

Humara-Gil, K. J. \& C. Cruz-Gómez. 2018. New records of benthic hydroids (Cnidaria: Hydrozoa) from the coast of Oaxaca, Mexico. Zootaxa 4455 (3): 454-470.

Jung, H. P. 2003. Two new records of marine hydromedusae (Cnidaria: Hydrozoa) in Korea. The Korean Journal of Systematic Zoology 19 (1): $111-117$.

KAPLOWITZ, M. D. 2000. Identifying ecosystem services using multiple methods: Lessons from the mangrove wetlands of Yucatan, Mexico. Agriculture and Human Values 17: 169-179.

Kramp, P. L. 1959. The Hydromedusae of the Atlantic Ocean and adjacent waters. Dana Report 46: 1-283.

КивотA, S. 2005. Distinction of two morphotypes of Turritopsis nutricula medusae (Cnidaria, Hydrozoa, Anthomedusae) in Japan, with reference to their different abilities to revert to the hydroidstage and their distinct geographical distributions. Biogeography 7: 41-50.

Loman-Ramos, L., U. Ordóñez-López \& L. Segura-Puertas. 2007. Variación espacial de la comunidad de medusas (Cnidaria) del sur del Golfo de México, durante el otoño de 1999. Hidrobiológica 17: 203-212.

Manzanilla-Domínguez, H. \& R. Gasca. 2004. Distribution and abundance of Phyllosoma larvae (Decapoda, Palinuridae) in the southern Gulf of Mexico and the western Caribbean Sea. Crustaceana 77 (1): 75-93.

Marina, T. I., J. A. Herrera-Silveira \& I. Medina-Gómez. 2017. Respuesta de la comunidad de fitoplancton y zooplancton al afloramiento de agua subterránea y surgencia costera en la península de Yucatán, México. Ecología Austral 27: 219-231.

Martell-Hernández, L. F., M. Sánchez-Ramírez \& A. Ocaña-Luna. 2014. Distribution of planktonic cnidarian assemblages in the southern Gulf of Mexico during autumn. Revista Chilena de Historia Natural 87: 18.
Mendoza-BecerRiL, M. A. 2006. Diversidad de Medusas (Phylum: Cnidaria) en la Laguna Madre, Tamaulipas. México. Tesis Profesional, Escuela Nacional de Ciencias Biológicas, Instituto Politécnico Nacional, México. $60 \mathrm{p}$.

Mendoza-Becerril, M. A., A. Ocaña-Luna, M. Sánchez-Ramirez \& L. SeguraPUERTAS. 2009. Primer registro de Phialella quadrata y ampliación del límite de distribución de ocho especies de hidromedusas (Hydrozoa) en el Océano Atlántico Occidental. Hidrobiológica 19: 257-267.

Mendoza-BecerrilL, M. A. \& A. C. Marques. 2013. Synopsis on the knowledge and distribution of the family Bougainvilliidae (Hydrozoa, Hydroidolina). Latin American Journal of Aquatic Research 41(5): 908-924.

Migletta, M. P., S. Piraino, S. Kubota \& P. Schuchert. 2007. Species in the genus Turritopsis (Cnidaria, Hydrozoa): a molecular evaluation. Journal of Zoological Systematics and Evolutionary Research 45(1): 11-19.

Nagata, R. M., M. Noguelra-JR. \& M. A. Haddad. 2014. Faunistic survey of Hydromedusae (Cnidaria, Medusozoa) from the coast of Paraná State, Southern Brazil. Zootaxa 3768 (3): 291-326.

Nascimento, L. S., M. Noguelra-JR., E. M. Viana \& J. G. Bersano. 2018. Biodiversity of planktonic hydrozoans from a subtropical estuary: evidence of assemblage structure change. Journal of the Marine Biological Association of the United Kingdom 99: 551-562.

NoguelRA-JR, M. 2012. Gelatinous zooplankton fauna (Cnidaria, Ctenophora and Thaliacea) from Baía da Babitonga (southern Brazil). Zootaxa 3398: 1-21.

Prudkovsky, A. A., I. A. Ekimova \& T. V. Neretina. 2019. A case of nascent speciation: unique polymorphism of gonophores within hydrozoan Sarsia Iovenii. Scientific Reports 9: 15567. D0I:10.1038/s41598019-52026-7

Pruski, S. \& M. P. MiglettA. 2019. Fluctuation and diversity of Hydromedusae (Hydrozoa, Cnidaria) in a highly productive region of the Gulf of Mexico inferred from high frequency plankton sampling. Peerj 7: e7848. D0l:10.7717/peerj.7848

Ramos, G. \& L. Segura-Puertas. 2004. Seasonal occurrence of reef-related medusae (Cnidaria) in the Western Caribbean Sea. Gulf and Caribbean Research 16: 1-9.

Rey, J. R., T. Kain \& D. E. De Freese. 1992. Observations on the feeding behavior and local distribution of Vallentinia gabriellae (Hydrozoa: Olindiidae): a new record from mangrove wetlands of the Indian river lagoon, Florida. Wetlands 12 (3): 225-229.

Reyes-Mendoza, 0., 0. Álvarez-Silva, X. Chiappa-Carrara \& C. Enriquez. 2020. Variability of the thermohaline structure of a coastal hypersaline lagoon and the implications for salinity gradient energy harvesting. Sustainable Energy Technologies and Assessments 38: 100645.

Ronowicz, M., A. L. Peña-Cantero, B. M. Casares, P. Kuklinski \& J. J. SotoÁngel. 2019. Assessing patterns of diversity, bathymetry and distribution at the poles using Hydrozoa (Cnidaria) as a model group. Hydrobiologia 833 (1): 25-51. DOI:10.1007/s10750-018-3876-5

Rosado-Espinosa, L. A., I. Ortegón-Aznar \& M. A. Ruíz-Zárate. 2012. Caracterización Estructural de los Mantos Algales como Recurso Natural 
Explotable en el Área Natural Protegida de Dzilam de Bravo, Yucatán, Mexico. Gulf and Caribbean Fisheries Institute 64: 208-215.

RusseL, F. S. 1953. The medusae of the British Isles. University Press, Cambridge. $530 \mathrm{p}$.

Sснисневт, P. 2006. The European athecate hydroids and their medusae (Hydrozoa, Cnidaria): Capitata Part 1. Revue Suisse de Zoologie 113 (2): 325-410.

Sснисневт, P. 2007. The European athecate hydroids and their medusae (Hydrozoa, Cnidaria): Filifera Part 2. Revue Suisse de Zoologie 114 (2): 195-396.

Sснисневт, P. 2020. World Hydrozoa Database. Available online at: http:// www.marinespecies.org/hydrozoa (downloaded October 15, 2020). DOI:10.14284/357

Segura-Puertas, L. 1992. Medusae (Cnidaria) from the Yucatan shelf and Mexican Caribbean. Bulletin of Marine Science 51: 353-359.

Segura-Puertas, L. \& M. Damas-Romero. 1997. Variación estacional de la comunidad de medusas (Cnidaria) en la laguna Bojórquez, Cancún, México. Hidrobiológica 7: 59-64.
Segura-Puertas, L., E. Suárez-Morales \& L. Cells. 2003. A checklist of the Medusae (Hydrozoa, Scyphozoa and Cubozoa) of Mexico. Zootaxa 194: 1-15.

Segura-Puertas, L., L. Celus \& L. Chiaverano. 2009. Medusozoans (Cnidaria: Cubozoa, Scyphozoa and Hydrozoa) of the Gulf of Mexico. In: Felder, D. L \& D. K. Camp (eds.). Gulf of Mexico. Origin, Waters and Biota. Vol. 1 Biodiversity. Texas A \& M University Press. Texas, pp. 369-379.

Vannucci-Mendez, M. 1948. On Vallentinia gabriellae $n$. sp. (Limnomedusae). Boletim da Faculdade de Filosofia Ciências e Letras Universidade de São Paulo. Serie Zoologia 13: 73-90.

Vannucci-Mendez, M. \& W. J. Rees. 1961. A revision of the genus Bougainvillia (Anthomedusae). Boletim do Instituto Oceanografico, São Paulo 11 (2): 57-100.

Vervoort, W. 2009. Corymorphato moensis Ikeda 1910 (Cnidaria, Hydrozoa): first record of a corymorphidhydro polyp from Indonesian waters and a review of the species of Corymorpha M. Sars, 1835. Zoologische Mededelingen 83: 759-776.

Wang, C., Z. Xu, J. Huang, D. Guo, M. Lin \& Z. XIA. 2016. Taxonomic notes on Hydroidomedusae (Cnidaria) from South China Sea III: Family Rathkeidae and Zancleopsidae. Zoological Systematics 41 (4): 392-403. 